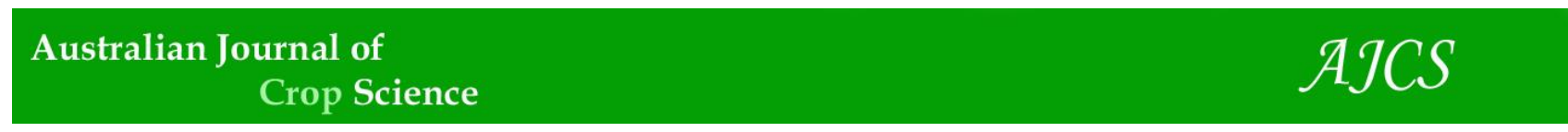

AJCS 10(7): 1000-1006 (2016)

ISSN:1835-2707

DOI: 10.21475/ajcs.2016.10.07.p7686

\title{
Study of morpho-agronomic diversity and oil content in desert gourd (Citrullus colocynthis (L.) Schrad.)
}

\author{
Kiran Menon $^{1 *}$, Neeru Sood ${ }^{1}$, Nanduri Kameswara Rao ${ }^{2}$ \\ ${ }^{1}$ Department of Biotechnology, Birla Institute of Technology \& Science- Pilani, Dubai Campus, Dubai \\ International Academic City, UAE \\ ${ }^{2}$ International Center for Biosaline Agriculture, Dubai, UAE
}

*Corresponding author: menonkiran86@gmail.com

\begin{abstract}
Citrullus colocynthis (L.) Schrad., also known as desert gourd, is a xerophytic perennial creeper. In a field trial conducted on sandy soil and under arid conditions in the United Emirates (UAE), 27 germplasm accessions were studied for their potential as feedstock for biodiesel production. All accessions were evaluated for two qualitative and eleven quantitative morpho-agronomic traits over a period of one year (November 2013- December 2014) in a field trial laid out in a randomized complete block design with three replicates. Analysis of the data revealed high variability among the accessions, with seed yields ranging between 12 and 374 grams per plant and seed oil content from 7.8 to $43.8 \%$ of seed weight. When the data were statistically analyzed using principal components analysis, traits of economic importance such as seed yield, oil content and number of fruits per plant grouped together, while others such as number of branches and branch length grouped separately. Agglomerative hierarchical clustering grouped the accessions into three main clusters. The extrapolated annual oil yield in several accessions exceeded 1 ton ha ${ }^{-1}$ (the highest being 3.44 tons $\mathrm{ha}^{-1}$ ) - showing the desert gourd to be a highly attractive biodiesel feedstock species for cultivation on marginal lands. The oil from most accessions had a free fatty acid content of less than $0.5 \%$ which is within suitable limits for biodiesel production. The observed variability in saponification values suggests that the oil is prone to oxidation upon storage. The wide range of variation found in this study for seed yield, oil quantity and oil quality provides the opportunity for genetic improvement to develop desert gourd into an economically-viable, non-edible, alternative biodiesel feedstock crop.
\end{abstract}

Keywords: Biodiesel feedstock; Citrullus colocynthis; Morho-agronomic diversity; Oil content.

Abbreviations: ASTM_American Society for Testing and Materials; ECPGR_European Cooperative Programme for Plant Genetic Resources; FYM_Farmyard Manure; ICBA_International Center for Biosaline Agriculture; NIH_National Institutes of Health; NPK_ Nitrogen: Phosphorous: Potassium; PCA_Principle Components Analysis; RCBD_Randomized Complete Block Design; UAE_ United Arab Emirates; USDA_United States Department of Agriculture.

\section{Introduction}

Citrullus colocynthis (L.) Schrad., also known as desert gourd (Handhal and Thumba in Arabic) is a member of the Cucurbitaceae family known for its high seed oil content (Achu et al., 2005). It bears yellow-green inedible fruits (Bande et al., 2012). It is a highly xerophytic perennial creeper native to the Mediterranean basin, the Middle East and South Asia. In the Arabian Peninsula, the plant often grows in the wild in sandy soils covering large areas and surviving under hyper-arid desert conditions with less than 50 $\mathrm{mm}$ annual precipitation. This plant also grows in coastal areas with salty or brackish waters (Qasim et al., 2011). The desert gourd was chosen for this study because of its perceived potential as a non-food biodiesel feedstock crop and the possibility for its cultivation in both arid and biophysically-marginal arid lands because it occurs naturally in such habitats.

The two main biodiesel feedstock crops cultivated worldwide are soybean and rapeseed, which are also two of the most widely consumed edible oils in the world. These crops require arable land for cultivation, thus not only increasing the price of edible oil, but also encroaching on land that can be used for the production of food crops. When blended with petroleum, biodiesel from the desert gourd is known to exhibit performance parameters similar to that of Jatropha (Jatropha curcas) - another non-food biodiesel crop (Mathur et al., 2012). The blends also have lower smoke opacity. The natural distribution of desert gourd suggests that compared to Jatropha, it could be more suitable for growing on lands generally inhospitable to produce crops of any kind or otherwise yield a profit. Additionally, the oil from desert gourd reportedly has lower viscosity (Pal et al., 2010), which could be of great advantage in terms of its potential as a biodiesel feedstock.

The desert gourd has been used in traditional Arabic medicine for centuries. Studies show that its root and callus extracts have anti-microbial (Gurudeeban et al., 2010), antiinflammatory (Rajamanickam et al., 2010), anti-diabetic (Gurudeeban and Ramanathan, 2010) and anti-oxidant (Gurudeeban et al., 2010) properties. Also being studied over several decades now, are its anti-cancer properties. A study as early as 1958 showed that the toxic and potent resinous constituents of the fruit caused damage to tumors in mice (Faust et al., 1958). Besides the known medicinal value, if its use in biodiesel production could be established, the desert 
gourd could potentially be cultivated in an economically feasible and sustainable manner on marginal lands and in regions with arid to hyper-arid environments.

In this paper, the morpho-agronomic characteristics and seed oil content of 27 desert gourd accessions are presented in order to assess the potential of this crop for large-scale cultivation and use as biodiesel feedstock. To the authors' knowledge, this is the first comprehensive study of desert gourd involving field trials.

\section{Results}

In the field trial, 27 accessions survived through the year of study (November 2013-December 2014) with a sufficient number of plants for observations. The remaining 10 accessions which were initially planted, either did not germination or died out within weeks after germination. While the mean daily temperatures during the growing period ranged between $20^{\circ} \mathrm{C}$ (January) and $36^{\circ} \mathrm{C}$ (July), the average maximum temperatures were between $28^{\circ} \mathrm{C}$ (January) and $46^{\circ} \mathrm{C}$ (July). The rainfall received during the study period amounted to $66.5 \mathrm{~mm}$.

\section{Morpho-agronomic evaluation}

The data recorded for morphological and agronomic characteristics showed considerable variability among the accessions (Table 1). The number of fruits per plant varied between 2 to 36 , seed yield from 11 to 373 grams per plant, and seed oil content from 7.8 to $43.8 \%$ of seed weight. Leaf water content which is a useful indicator of plant water balance and is intimately related to several physiological variables, such as leaf turgor, stomatal conductance, transpiration, photosynthesis and respiration, did not differ significantly and ranged from $76 \%$ to $85 \%$, with a standard deviation of 2.67 among the accessions. The fresh and dry weights of leaves, from which the moisture content was calculated, also showed no significant variations among the accessions (data not presented).

The correlation matrix (Table 2) showed positive correlation between growth-related characteristics such as number of branches, vine length and leaf size. Interestingly, the number of primary branches and vine length were negatively correlated with number of fruits and yield per plant $(r<0.00)$. The yield per plant did not correlate positively with any parameter other than the number of fruits $(r=0.481)$. The number of fruits also correlated positively with seed oil content ( $\mathrm{r}=0.134)$ (Table 2).

Based on the screen plot from the principal components analysis, the first two components, contributing to 46.49 and $15.29 \%$ of the variation respectively were used to generate a biplot (Fig 1). From the results of analysis presented in the latent vector loading table (Table 3), it is shown that traits of economic interest such as yield per plant, number of fruits, and oil content, all loaded more significantly on the second component. This meant that these traits were associated more strongly with each other than with traits associated with vegetative growth. The dendrogram from the agglomerative hierarchical clustering of all accessions based on the collected agronomic data is presented in Fig 2.

\section{Yield}

With the spacing of four plants per $\mathrm{m}^{2}$ used in this study, the extrapolated annual seed yield among the accessions ranged from 0.47 to 14.95 tons $\mathrm{ha}^{-1}$, with an overall mean of 5.17 tons ha ${ }^{-1}$. The yield was highest in KMK 1 (14.95 tons ha-1), followed by RMS 227 (12.37 tons ha ${ }^{-1}$ ) and RMS 244 (11.63 tons $\left.\mathrm{ha}^{-1}\right)$. The oil yield extrapolated from the data varied between 0.07 and 3.44 tons ha ${ }^{-1}$ with an overall mean of 0.98 ton $\mathrm{ha}^{-1}$. While several accessions had oil yield exceeding 1 ton $\mathrm{ha}^{-1}$, it was highest in RMS 228 (3.44 tons ha $\left.{ }^{-1}\right)$, followed by RMS $244\left(2.28\right.$ tons ha $\left.{ }^{-1}\right)$.

\section{Oil characteristics}

The oil extracted from the seeds, like many other characteristics varied in composition among the accessions (Table 4). The saponification value, which is an indicator of the average molecular weight, ranged from 203.8 to 211.4 in this study. Oil from nine accessions (RMS 246, RMS 254, RMS 234, RMS 231, RMS 257, RMS 228, RMS 256, RMS 250 and RMS 240) had a free fatty acid content higher than $0.5 \%$ and the average kinematic viscosity at $40^{\circ} \mathrm{C}$ was determined to be $33.26 \mathrm{~mm}^{2} \mathrm{~s}^{-1}$.

\section{Discussion}

This study on the desert gourd was carried out over a period of one year under growing conditions representative of the harsh desert environment with main purpose to evaluate the potential of the species for use in biodiesel production and identifying accessions with high seed and oil yields. The results indeed showed that desert gourd is an attractive candidate for development as a biodiesel feedstock crop, with yields comparable to other oilseed crops such as soybean and rapeseed. The correlation matrix showed that higher yielding varieties generally have lower values of vine length and other growth factors. From a large-scale cultivation point of view, this means a higher density of plants can be achieved per hectare, increasing the yield per hectare (Diepenbrock, 2000). The principal components analysis showed that characteristics of agricultural and economic interest such as yield per plant, oil content and number of fruits, group together and load more significantly on the first component, indicating the scope to further improve the species through selection and breeding.

If the accessions are ranked on the basis of important characteristics such as oilseed yield, oil yield and number of fruits per plant, accessions KMK1, RMS 227, RMS 228 and RMS 244 are the best performing among the 27 accessions studied. If oil quality, mainly fatty acid content of $<0.5 \%$ is also taken into consideration, RMS 227 appears to be the most promising accession in this study. From the hierarchical clustering and the biplot of principal components analysis, it can be seen that the accessions grouped into two large clusters, with the exceptions of accessions PI 388770 and PI 525082. Accessions PI 388770 and PI 525082 were low yielding and similar to each other in their highly branched growth habit and greater vegetative growth in terms of vine length and leaf size compared to other accessions. Accessions RMS 228 and RMS 239, though loaded separately in the PCA biplot along the second component because of their high yield, grouped together with accessions RMS 246, RMS 257, RMS 255, RMS 220, RMS 245, RMS 244, RMS 258, RMS 247, RMS 237, RMS 240, RMS 249, RMS 215 and KMK1 in the dendrogram from cluster analysis, to form one large group composed of the higher yielding accessions.

Based on the plant density used in present studies, the extrapolated mean annual oil yield of 0.98 ton $\mathrm{ha}^{-1}$ is greater than that of soybean and rapeseed oil yields of 0.5-0.6 ton ha ${ }^{1}$ (Clemente and Cahoon, 2009; Rondanini et al., 2012). The saponification value range of desert gourd corresponded with an average C16-C18 fatty acid chain length (Sanford et al., 
Table 1. Mean values of morpho-agronomic data for desert gourd accessions. Standard deviations for each quantitative characteristic across accessions is provided as an indicator of variability.

\begin{tabular}{|c|c|c|c|c|c|c|c|c|c|c|c|c|c|c|}
\hline Identity & Origin & $\begin{array}{l}\text { No. of primary } \\
\text { branches }\end{array}$ & $\begin{array}{l}\text { Vine length } \\
(\mathrm{cm})\end{array}$ & $\begin{array}{l}\text { Leaf length } \\
(\mathrm{cm})\end{array}$ & $\begin{array}{l}\text { Leaf breadth } \\
(\mathrm{cm})\end{array}$ & $\begin{array}{c}\text { Leaf } \\
\text { moisture } \\
(\%)\end{array}$ & $\begin{array}{l}\text { No. of } \\
\text { fruits per } \\
\text { plant }\end{array}$ & $\begin{array}{c}\text { Fruit } \\
\text { diameter } \\
(\mathrm{cm})\end{array}$ & $\begin{array}{c}\text { Seed oil } \\
\text { content } \\
(\%)\end{array}$ & $\begin{array}{c}\text { Seed } \\
\text { yield per } \\
\text { plant }(\mathrm{g})\end{array}$ & $\begin{array}{l}1000 \text { seed } \\
\text { weight }(\mathrm{g})\end{array}$ & $\begin{array}{c}\text { Seed Size/ } \\
\text { Surface area } \\
\left(\mathrm{cm}^{2}\right)\end{array}$ & $\begin{array}{l}\text { Seed } \\
\text { color }^{*}\end{array}$ & $\begin{array}{l}\text { Fruit } \\
\text { color" }\end{array}$ \\
\hline RMS 215 & UAE & 3.20 & 65 & 6.55 & 3.80 & 82.38 & 5.20 & 6.78 & 12.0 & 108.94 & 18 & 0.19 & 1 & 1 \\
\hline RMS 220 & UAE & 7.00 & 68 & 6.90 & 4.25 & 81.00 & 23.00 & 4.65 & 13.2 & 119.20 & 22 & 0.16 & 2 & 2 \\
\hline RMS 227 & UAE & 4.00 & 65 & 7.16 & 3.58 & 84.02 & 24.89 & 7.40 & 13.6 & 309.40 & 22 & 0.14 & 1 & 1 \\
\hline RMS 228 & UAE & 1.25 & 27 & 5.20 & 3.65 & 79.21 & 36.00 & 8.10 & 30.4 & 282.73 & 18 & 0.11 & 1 & 3 \\
\hline RMS 231 & UAE & 2.29 & 142 & 9.77 & 6.13 & 76.40 & 11.14 & 6.29 & 22.8 & 80.60 & 36 & 0.23 & 1 & 1 \\
\hline RMS 234 & UAE & 3.13 & 124 & 6.36 & 3.29 & 76.05 & 10.63 & 5.45 & 14.4 & 95.86 & 36 & 0.25 & 2 & 1 \\
\hline RMS 237 & UAE & 4.25 & 47 & 7.86 & 3.15 & 83.49 & 14.13 & 5.39 & 16.0 & 142.70 & 20 & 0.15 & 1 & 1 \\
\hline RMS 239 & UAE & 1.67 & 32 & 5.44 & 3.18 & 79.15 & 29.83 & 6.43 & 16.0 & 208.24 & 18 & 0.15 & 2 & 2 \\
\hline RMS 240 & UAE & 4.00 & 37 & 6.00 & 3.23 & 79.75 & 9.00 & 5.20 & 19.4 & 92.40 & 26 & 0.14 & 2 & 1 \\
\hline RMS 244 & UAE & 2.86 & 55 & 4.24 & 2.18 & 79.80 & 14.29 & 8.40 & 19.6 & 290.85 & 22 & 0.14 & 1 & 1 \\
\hline RMS 245 & UAE & 3.23 & 91 & 8.17 & 4.54 & 76.15 & 3.15 & 7.20 & 27.0 & 135.91 & 30 & 0.19 & 2 & 1 \\
\hline RMS 246 & UAE & 3.77 & 61 & 5.67 & 3.98 & 78.34 & 11.31 & 6.80 & 12.2 & 83.75 & 24 & 0.15 & 2 & 1 \\
\hline RMS 247 & UAE & 2.13 & 89 & 7.26 & 5.30 & 84.61 & 18.38 & 6.21 & 43.8 & 97.83 & 20 & 0.15 & 2 & 1 \\
\hline RMS 249 & UAE & 1.67 & 23 & 4.15 & 2.85 & 80.04 & 9.33 & 6.53 & 15.0 & 122.27 & 24 & 0.14 & 1 & 1 \\
\hline RMS 250 & UAE & 2.29 & 30 & 5.43 & 3.17 & 82.67 & 2.71 & 7.30 & 10.0 & 24.63 & 24 & 0.15 & 1 & 1 \\
\hline RMS 254 & UAE & 1.44 & 49 & 4.68 & 3.15 & 84.59 & 9.67 & 7.13 & 28.2 & 50.10 & 24 & 0.14 & 1 & 1 \\
\hline RMS 255 & UAE & 3.17 & 47 & 5.32 & 3.15 & 80.06 & 14.83 & 4.30 & 18.0 & 77.40 & 24 & 0.13 & 1 & 1 \\
\hline RMS 256 & UAE & 4.77 & 185 & 9.25 & 5.99 & 81.25 & 8.62 & 7.60 & 19.6 & 160.56 & 38 & 0.28 & 3 & 2 \\
\hline RMS 257 & UAE & 1.80 & 21 & 5.26 & 3.29 & 77.80 & 22.20 & 5.38 & 22.6 & 139.95 & 32 & 0.11 & 2 & 1 \\
\hline RMS 258 & UAE & 2.14 & 55 & 5.98 & 3.29 & 79.42 & 10.71 & 8.92 & 17.6 & 116.44 & 18 & 0.14 & 1 & 2 \\
\hline KMK1 & UAE & 2.50 & 23 & 4.57 & 3.14 & 80.55 & 3.50 & 5.28 & 9.4 & 373.86 & 18 & 0.13 & 1 & 1 \\
\hline KMK3 & UAE & 5.30 & 102 & 6.67 & 3.20 & 83.90 & 8.80 & 5.40 & 13.0 & 81.12 & 22 & 0.11 & 1 & 1 \\
\hline PI 386024 & Iran & 4.93 & 81 & 8.13 & 4.62 & 83.65 & 2.53 & 6.47 & 26.2 & 38.81 & 54 & 0.16 & 1 & 1 \\
\hline PI 388770 & Morocco & 14.00 & 250 & 13.15 & 7.99 & 84.40 & 2.44 & 8.20 & 16.2 & 11.90 & 48 & 0.28 & 1 & 1 \\
\hline $\begin{array}{l}\text { PI } 525080 \\
\end{array}$ & Egypt & 5.38 & 135 & 7.32 & 3.67 & 84.23 & 6.63 & 8.36 & 27.6 & 123.76 & 52 & 0.25 & 2 & 1 \\
\hline PI 525082 & Egypt & 12.00 & 220 & 9.45 & 5.73 & 79.45 & 2.33 & 15.29 & 31.0 & 47.56 & 72 & 0.41 & 1 & 2 \\
\hline \multirow{3}{*}{$\begin{array}{l}\text { PI } 537277 \\
\end{array}$} & Pakistan & 2.67 & 72 & 7.24 & 3.85 & 78.36 & 9.33 & 8.90 & 13.0 & 74.60 & 28 & 0.24 & 4 & 1 \\
\hline & Mean & 3.96 & 81.3 & 6.78 & 3.98 & 80.77 & 12.02 & 7.01 & 19.55 & 129.31 & 29.3 & 0.18 & NA & NA \\
\hline & $\begin{array}{l}\text { Standard } \\
\text { deviation (+/-) }\end{array}$ & 2.91 & 58.95 & 1.97 & 1.25 & 2.67 & 8.57 & 2.06 & 7.82 & 88.61 & 13.12 & 0.07 & NA & NA \\
\hline
\end{tabular}

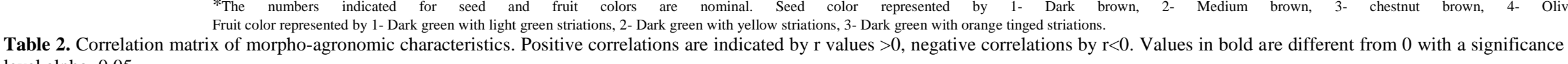
level alpha $=0.05$.

\begin{tabular}{|c|c|c|c|c|c|c|c|c|c|c|c|c|}
\hline Trait & $\begin{array}{l}\text { No. of } \\
\text { branches }\end{array}$ & $\begin{array}{l}\text { Vine length } \\
(\mathrm{cm})\end{array}$ & $\begin{array}{l}\text { Average leaf } \\
\text { length }(\mathrm{cm})\end{array}$ & $\begin{array}{l}\text { Average leaf } \\
\text { breadth }(\mathrm{cm})\end{array}$ & $\begin{array}{l}\text { No. of fruit } \\
\text { per plant }\end{array}$ & Fruit diameter $(\mathrm{cm})$ & $\begin{array}{c}\text { Seed Oil } \\
\text { content (\%) }\end{array}$ & $\begin{array}{c}\text { Seed yield } \\
\text { per plant }(\mathrm{g})\end{array}$ & $\begin{array}{l}1000 \text { seed } \\
\text { weight }(\mathrm{g})\end{array}$ & $\begin{array}{c}\text { Seed size } \\
\left(\mathrm{cm}^{2}\right)\end{array}$ & $\begin{array}{l}\text { Seed } \\
\text { color }\end{array}$ & $\begin{array}{l}\text { Fruit } \\
\text { color }\end{array}$ \\
\hline No. of branches & 1 & 0.797 & 0.751 & 0.668 & -0.367 & 0.458 & 0.013 & -0.35 & 0.683 & 0.668 & -0.099 & 0.059 \\
\hline Vine length $(\mathrm{cm})$ & 0.797 & 1 & 0.869 & 0.835 & -0.415 & 0.51 & 0.223 & -0.387 & 0.754 & 0.856 & 0.09 & 0.054 \\
\hline Average Leaf length $(\mathrm{cm})$ & 0.751 & 0.869 & 1 & 0.911 & -0.335 & 0.323 & 0.177 & -0.406 & 0.621 & 0.685 & 0.092 & -0.002 \\
\hline Average leaf breadth $(\mathrm{cm})$ & 0.668 & 0.835 & 0.911 & 1 & -0.266 & 0.325 & 0.304 & -0.383 & 0.574 & 0.646 & 0.105 & 0.11 \\
\hline No. of fruits per plant & -0.367 & -0.415 & -0.335 & -0.266 & 1 & -0.234 & 0.134 & 0.481 & -0.469 & -0.436 & 0.065 & 0.522 \\
\hline Fruit diameter $(\mathrm{cm})$ & 0.458 & 0.51 & 0.323 & 0.325 & -0.234 & 1 & 0.307 & -0.108 & 0.592 & 0.695 & -0.015 & 0.349 \\
\hline Oil content $(\%)$ & 0.013 & 0.223 & 0.177 & 0.304 & 0.134 & 0.307 & 1 & -0.127 & 0.34 & 0.17 & 0.005 & 0.196 \\
\hline YPP $(g)$ & -0.35 & -0.387 & -0.406 & -0.383 & 0.481 & -0.108 & -0.127 & 1 & -0.43 & -0.354 & -0.095 & 0.253 \\
\hline 1000 seed weight $(\mathrm{g})$ & 0.683 & 0.754 & 0.621 & 0.574 & -0.469 & 0.592 & 0.34 & -0.43 & 1 & 0.795 & 0.04 & -0.004 \\
\hline Seed Size $\left(\mathrm{cm}^{2}\right)$ & 0.668 & 0.856 & 0.685 & 0.646 & -0.436 & 0.695 & 0.17 & -0.354 & 0.795 & 1 & 0.243 & 0.114 \\
\hline Seed color & -0.099 & 0.09 & 0.092 & 0.105 & 0.065 & -0.015 & 0.005 & -0.095 & 0.04 & 0.243 & 1 & 0.036 \\
\hline Fruit color & 0.059 & 0.054 & -0.002 & 0.11 & 0.522 & 0.349 & 0.196 & 0.253 & -0.004 & 0.114 & 0.036 & 1 \\
\hline
\end{tabular}




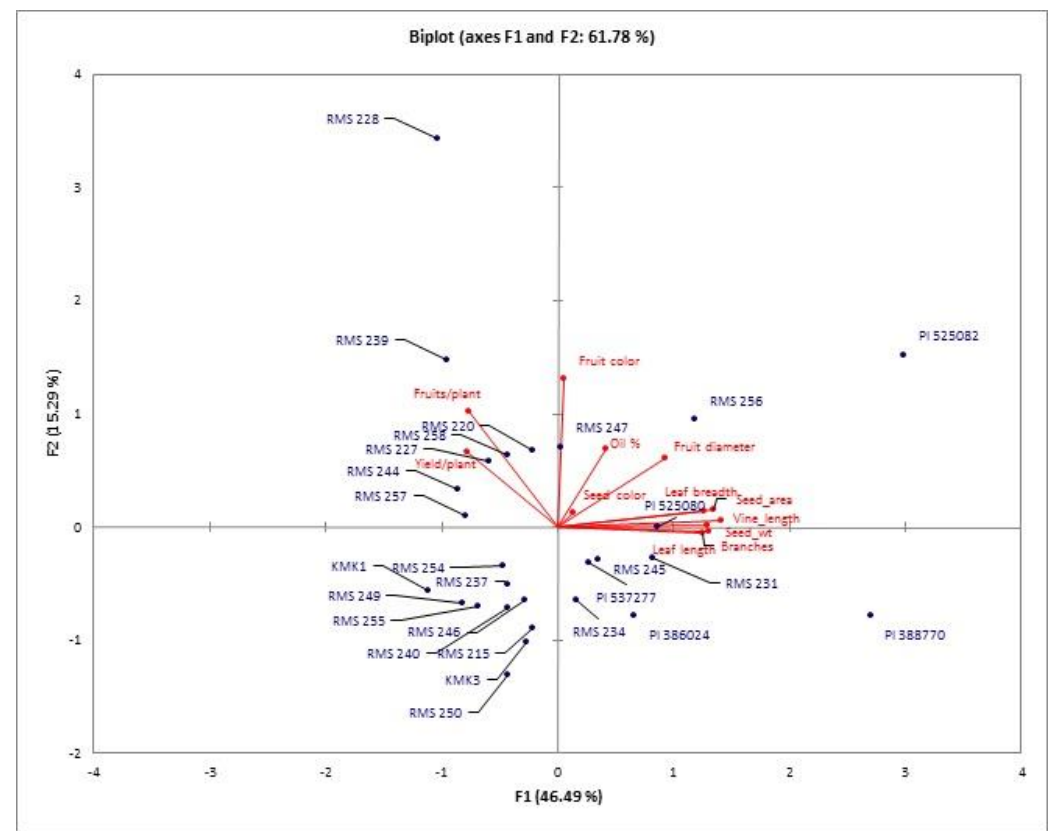

Fig 1. Biplot of distribution of desert gourd accessions based on two principal components. Component 1 from the loading vector table is represented by the $\mathrm{X}$-axis and component 2 by the $\mathrm{Y}$-axis. Individual points represent accessions, as identified by the labels, and the central vectors represent the loading of individual characteristics (also labeled) along the two components.

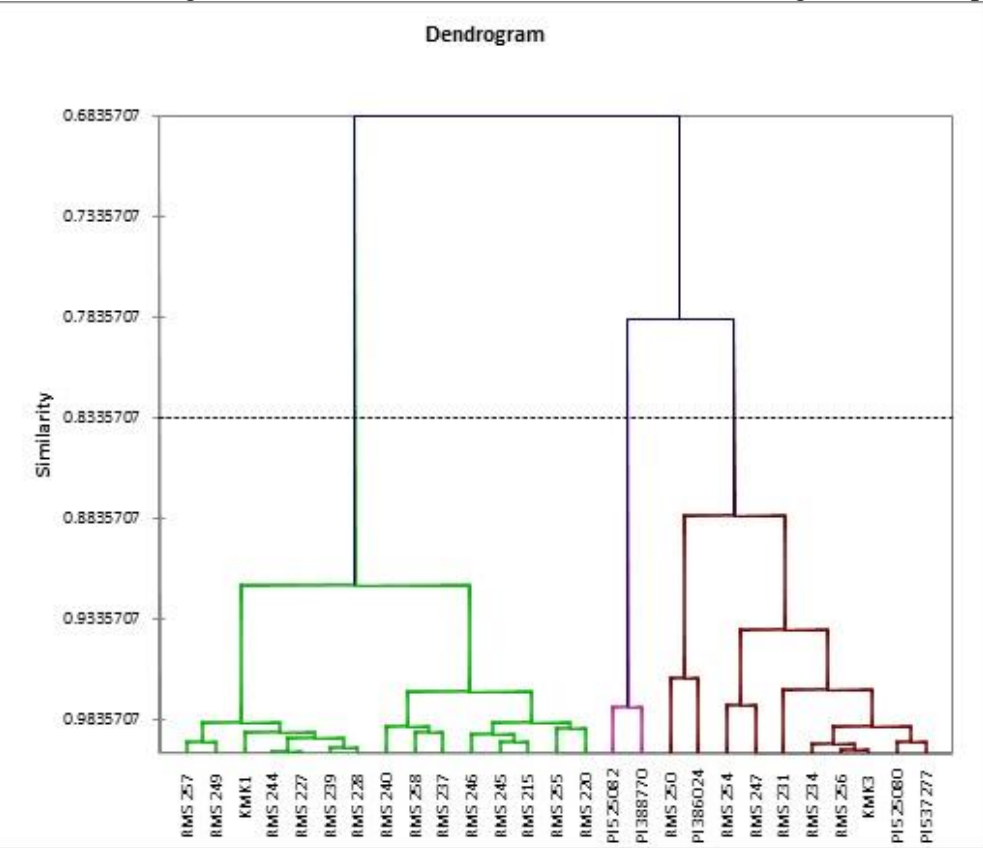

Fig 2. Dendrogram generated from agglomerative heirarchical clustering based on unweighted pair-group average of 27 desert gourd accessions.

2009), which is within the acceptable limits for biodiesel production. While Pal et al. (2010) already reported that seed oil from desert gourd can be used as an alternative fuel with better performance and lower emissions compared with diesel, Giwa et al. (2010) also found that oil from Egusi melon, a close relative of desert gourd has $60 \%$ linoleic acid - a polyunsaturated omega-6 C18 fatty acid with low viscosity, which make it well-suited for biodiesel production due to improved fuel flow characteristics compared to other biodiesel feedstocks.

The free fatty acid content in biodiesel feedstock oil is an important parameter because an excess of it can cause the formation of emulsion during transesterification, which makes the separation of biodiesel difficult besides resulting in yield loss. According to ASTM standards, free fatty acid content should be less than $0.5 \%$ by weight in biodiesel feedstock oil (Atadashi et al., 2012). High free fatty acid content makes the oil prone to rancidity due to hydrolysis by enzymes or oxidation upon storage. Considering that the majority of the accessions studied have free fatty acid content lower than $0.5 \%$ and that large variability exists between accessions for seed and oil yields, it should be possible to improve the desert gourd through selection and hybridization for low free fatty acid content combined with high oil yield potential and thus develop it into an economically-important non-edible biodiesel feedstock crop. 
Table 3. Latent Vector Loadings for two principal components for the various traits in 27 desert guard accessions.

\begin{tabular}{lcc}
\hline Trait & Component \\
\hline & 1 & 2 \\
\hline 1000 seed weight $(\mathrm{g})$ & 0.860 & 0.009 \\
Average leaf length $(\mathrm{cm})$ & 0.872 & -0.027 \\
Average leaf breadth $(\mathrm{cm})$ & 0.839 & 0.095 \\
Branch length $(\mathrm{cm})$ & 0.946 & 0.038 \\
Fruit color & 0.036 & 0.872 \\
Fruit diameter $(\mathrm{cm})$ & 0.615 & 0.405 \\
No. of branches & 0.830 & -0.031 \\
No. of fruits per plant & -0.510 & 0.686 \\
Oil content $(\%)$ & 0.277 & 0.459 \\
Seed surface area $\left(\mathrm{cm}^{2}\right)$ & 0.894 & 0.101 \\
Seed color & 0.094 & 0.082 \\
Seed yield per plant $(\mathrm{g})$ & -0.516 & 0.446 \\
\hline
\end{tabular}

Table 4. Free fatty acid content, Saponification Value and Kinematic viscosity at $26^{\circ} \mathrm{C}$ in 27 desert gourd accessions.

\begin{tabular}{lccc}
\hline Identity & $\begin{array}{c}\text { FFA } \\
(\text { wt } \%)\end{array}$ & $\begin{array}{c}\text { Saponification value } \\
(\mathrm{mg} \mathrm{KOH} / \mathrm{g})\end{array}$ & $\begin{array}{c}\text { Kinematic } \\
\text { viscosity (mm2/s) }\end{array}$ \\
\hline RMS 215 & 0.23 & 205.40 & 25.51 \\
RMS 220 & 0.02 & 208.90 & 27.43 \\
RMS 227 & 0.04 & 210.60 & 25.75 \\
RMS 228 & 1.13 & 209.80 & 25.75 \\
RMS 231 & 2.89 & 203.90 & 23.47 \\
RMS 234 & 1.27 & 205.40 & 28.57 \\
RMS 239 & 0.04 & 204.70 & 26.87 \\
RMS 240 & 1.43 & 205.30 & 33.14 \\
RMS 244 & 0.23 & 204.30 & 32.65 \\
RMS 245 & 0.08 & 207.60 & 27.99 \\
RMS 246 & 1.09 & 205.60 & 25.14 \\
RMS 247 & 0.02 & 203.80 & 35.71 \\
RMS 249 & 0.46 & 210.57 & 26.87 \\
RMS 250 & 0.70 & 207.80 & 31.34 \\
RMS 254 & 1.67 & 204.30 & 24.63 \\
RMS 255 & 0.03 & 210.30 & 23.47 \\
RMS 256 & 1.01 & 205.90 & 35.43 \\
RMS 257 & 1.21 & 208.60 & 25.14 \\
RMS 258 & 0.02 & 208.90 & 25.14 \\
KMK1 & 0.04 & 211.10 & 26.29 \\
KMK3 & 0.08 & 208.17 & 28.57 \\
PI 386024 & 0.03 & 207.35 & 26.53 \\
PI 388770 & 0.05 & 206.10 & 28.57 \\
PI 525080 & 0.04 & 205.89 & 24.63 \\
PI 525082 & 0.23 & 211.40 & 30.86 \\
PI 537277 & 0.56 & 207.38 & 23.51 \\
\hline Mean & 0.56 & 2.42 & 3.47 \\
Standard Deviation $(+/-)$ & 0.7 & & \\
\hline
\end{tabular}

\section{Materials and Methods}

\section{Plant materials}

Thirty accessions of desert gourd collected from different locations within the UAE (Shahid and Rao, 2014) and seven accessions, originating from arid environments obtained from the United States Department of Agriculture (USDA) were used in this study. The geographical coordinates of the local collection sites are listed in Supplementary Table 1 and a schematic map of the collection sites is presented in Supplementary Fig 1 . The details of accessions obtained from the USDA are provided in Supplementary Table 2.

\section{Experimental design}

The accessions were sown in mid-November 2013 using a randomized complete block design (RCBD) with three replicates at the International Center for Biosaline
Agriculture (ICBA) research station $\left(25.09^{\circ} \mathrm{N}, 55.38^{\circ} \mathrm{E}\right)$ on the outskirts of Dubai, UAE. The soils at the research station were sandy in texture (sand $98 \%$, silt $1 \%$, and clay $1 \%$ ), calcareous $\left(50-60 \% \quad \mathrm{CaCO}_{3}\right.$ equivalents), porous $(45 \%$ porosity) and moderately alkaline ( $\mathrm{pH} 8.22$ ), being very low in organic matter $(<1 \%)$. Prior to planting, the soil fertility of the experimental site was improved by incorporating farmyard manure (FYM) at the rate of 40 tons ha ${ }^{-1}$. The seeds were planted to a depth of $2-3 \mathrm{~cm}$ in field plots each of four rows of $2 \mathrm{~m}$ and with a spacing of $1 \mathrm{~m}$ between two plots. The distance between rows as well as between the plants within the row was $50 \mathrm{~cm}$. The plants were irrigated twice a day by drip irrigation with low-quality municipal water that had an electrical conductivity of $0.3-0.5 \mathrm{dS} \mathrm{m}^{-1}$. Urea (46\%) was applied one month after planting followed by NPK (20$20-20)$ at $30 \mathrm{~kg} \mathrm{ha}^{-1}, 60$ days after planting. Prior to sowing, the seeds were scarified with sand paper, soaked for $48 \mathrm{hrs}$ and incubated at $30^{\circ} \mathrm{C}$ for $24 \mathrm{hrs}$ to overcome dormancy observed in the freshly-harvested seeds (Menon et al., 2014). 


\section{Morpho-agronomic characterization}

The accessions were characterized for two exclusively qualitative (fruit and seed color) and 11 quantitative traits (such as branching, vine length, leaf, fruit and seed characteristics, and oil content (see Table 1), largely based on the Descriptors for Citrullus (ECPGR, 2008). Measurements such as the vine length, leaf length and breadth, and number of branches were recorded at the end of the study period in December 2014. The total number of mature fruits was recorded after harvesting them periodically throughout the year, as most accessions flowered more than twice a year under irrigated conditions. Data were collected from five randomly selected plants in each plot and the averages were calculated. Leaf length and breadth were noted for approximation of leaf size, with the fifth leaf on a primary branch set as the standard. Twenty leaves were collected at random from each plot for fresh and dry weight measurements as an indicator of plant biomass and vegetative growth. Leaf moisture content was calculated from the data as an estimate of plant water balance in different accessions using the formula (Afzal et al., 2010):

Leaf moisture content

$$
=\frac{\text { Fresh weight }- \text { Dry weight }}{\text { Fresh weight }} \times 100
$$

Seed weight (per 1000 seeds) was determined using a seed counter Contador. Seed size (surface area of the large, flat phase) was calculated from images using the ImageJ Image processing and the analysis software provided as freeware by the National Institutes of Health (NIH), USA, which is a benchmark tool for image analysis and area measurements (Bylesjö et al., 2008; Johnson et al., 2009). The average per plant seed yield was extrapolated to tons $\mathrm{ha}^{-1}$, assuming a plant density of 6.25 plants per $\mathrm{m}^{2}$.

\section{Seed oil content}

Fifty grams of seed from each plot, in triplicates for each accession was used to extract oil following the conventional method of solvent extraction (n-hexane) with a Soxhlet apparatus (Cravotto et al., 2011). Hexane was removed from extracted oil using a rotary evaporator.

\section{Oil characterization}

Saponification value and free fatty acid (calculated from Acid Number) were determined using standard American Society for Testing and Materials (ASTM) test methods (D5558, D664) (Wang et al., 2014; Shao and Agblevor, 2015). Dynamic viscosity was calculated using a digital viscometer (model LT-730 from Labtronics).

\section{Statistical analysis}

Variations in quantitative traits were explained by using descriptive statistics such as means, ranges and standard deviation. Principal component analysis (PCA) was performed on the correlation matrix of the variables and represented graphically using a biplot display. Agglomerative hierarchical cluster analysis was carried out based on the unweighted pair-group method with arithmetic averages of the traits that differed significantly. All calculations and analyses were conducted using XLSTAT (version 2015.4) with MSExcel (@ Addinsoft).

\section{Conclusion}

The desert gourd, a xerophytic perennial creeper has multiple uses for its oil and medicinal compounds. In the field trial involving of 27 accessions - most of them collected from the wild in the UAE, significant differences were observed for morpho-agronomic traits as well as oil quantity and quality. The extrapolated oil yield in some accessions was found to be higher than in most other oil-yielding crops - especially soybean and corn, the two main globally cultivated biodiesel feedstock crops. Most of the accessions of the desert gourd were also found to be higher yielding than Jatropha - a nonedible biodiesel crop with the reported oil yields of about 1.5 to 2 tons $\mathrm{ha}^{-1}$ (Sujatha et al., 2008). Jatropha yields are however, highly dependent on climate and soil conditions (Tikkoo et al., 2013). In current studies, the maximum oil yields obtained in desert gourd were similar to the yield reported in Calophyllum inophyllum (4.68 tons $\mathrm{ha}^{-1}$ ) but lower than that of palm oil (5.95 tons ha ${ }^{-1}$ ) (Atabani et al., 2012). Nevertheless, compared to other biodiesel feedstock crops, desert gourd is more likely to be tolerance to marginal growing conditions with lower water requirements because of its natural adaptation to desert environments. This however, needs confirmation through well-designed field trials. Oil from the desert gourd appears to have properties suitable for biodiesel production, but may be prone to oxidation and could require addition of antioxidants for storage. The low viscosity of desert gourd oil has especial advantage because it doesn't need blending with petroleum fuels before use, unlike the highly viscous oils. In addition to its potential as a biodiesel feed stock crop, the medicinal properties of desert gourd merit further investigation as extracts are rich in a number of bioactive phytochemicals and purification and isolation of the bioactive compounds and cell cytotoxicity assays could lead to the identification of novel drugs.

\section{Acknowledgments}

We would like to thank the management at ICBA for facilitating and providing resources for field work in this study. We extend sincere gratitude to Dr. Mohammad Shahid for collecting the germplasm and Saiful Islam for his support in the field work.

\section{References}

Achu M, Fokou E, Tchiegang C, Fotso M, Tchouanguep F (2005) Nutritive value of some cucrbitaceae oilseeds from different regions in cameroon. Afr J Biotechnol. 11:13291334.

Afzal A, Mousavi SF, Khadem AM (2010) Estimation of leaf moisture content by measuring the capacitance. J Agr Sci Tech. 12:339-346.

Atabani AE, Mahlia TM, Badruddin IA, Masjuki HH, Chong WT, Lee KT (2013) Investigation of physical and chemical properties of potential edible and non-edible feedstocks for biodiesel production, a comparative analysis. Renew Sust Energ Rev. 21:749-755.

Atadashi IM (2012) Production of biodiesel using high free fatty acid feedstocks. Renew Sust Energ Rev. 16:32753285.

Bande Y, Adam N, Azmi Y, Jamarei O (2012) Determination of selected physical properties of egusi melon (Citrullus lanatus) seeds. J Basic Appl Sci. 8:257-265.

Bylesjö M, Segura V, Soolanayakanahally RY, Rae AM, Trygg J, Gustafsson P, Jansson S, Street NR (2008) 
Lamina: a tool for rapid quantification of leaf size and shape parameters. BMC Plant Biol. 8:82.

Clemente TE, Cahoon EB (2009) Soybean oil: genetic approaches for modification of functionality and total content. Plant Physiol.151(3):1030-1040.

Cravotto GC (2011) Extraction of kiwi seed oil: soxhlet versus four different non-conventional techniques. Nat Prod Res. 25(10):974-981.

Diepenbrock W (2000) Yield analysis of winter oilseed rape (Brassica napus L.): a review. Field Crops Res. 67(1):3549.

ECPGR (2008) Minimum descriptor list for cucurbita spp. European cooperative programme for plant genetic resources:

http://www.ecpgr.cgiar.org/fileadmin/templates/ecpgr.org/u pload/NW_and_WG_UPLOADS/Cucurbits_DescriptorList s.pdf

Faust RE, Cwalina GE, Ramstad E (1958) The antineoplastic action of chemical fractions of the fruit of Citrullus colocynthis on sarcoma-37. J Pharm Sci. 47:1-5.

Giwa S, Abdullah LC, Adam, NM (2010) Investigating "egusi"(Citrullus colocynthis L.) seed oil as potential biodiesel feedstock. Energies. 3:607-618.

Gurudeeban S, Ramanathan T (2010) Antidiabetic effect of Citrullus colocynthis in alloxon-induced diabetic rats. Inventi Rapid: Ethno pharmacology. 1:112.

Gurudeeban S, Rajamanickam E, Ramanathan T, Satyavani K (2010) Antimicrobial activity of Citrullus colocynthis in gulf of mannar. Int J Curr Res. 2:78-81.

Gurudeeban S, Ramanathan T, Satyavani K (2010) Antioxidant and radical scavenging activity of Citrullus colocynthis. Inventi Rapid: Nutraceuticals. 1:38.

Johnson DM, Woodruff DR, McCulloh KA, Meinzer FC (2009) Leaf hydraulic conductance, measured in situ, declines and recovers daily: leaf hydraulics, water potential and stomatal conductance in four temperate and three tropical tree species. Tree Physiol. 29:879-887.

Mathur Y, Poonia M, Pandel U, Singh R (2012) Performance and emission characteristics of diesel engine using low concentration thumba oil diesel blends. Int J Wind Renew Energ. 1:108-113.

Menon K, Jayakumar AP, Shahid M, Sood N, Rao NK (2014) Seed dormancy and effect of salinity on germination of Citrullus colocynthis. Int J Env Sci Dev. 5:566-569.

Pal A, Kachhwaha S, Maji S, Babu M (2010) Thumba (Citrullus colocynthis) seed oil: a sustainable source of renewable energy for biodiesel production. J Sci Ind Res. 69:384-389.
Qasim M, Khan MA, Gulzar S (2011) Halophytes as medicinal plants. In: Ozturk M. Mermut AR, Celik A (eds) Urbanization, land use, land degradation and environment. Daya Publishing House, Turkey.

Rajamanickam E, Gurudeeban S, Ramanathan T, Satyavani K (2010) Evaluation of anti inflammatory activity of Citrullus colocynthis. Int J Curr Res. 2:67-69.

Rao NK, Shahid M (2014) Diversity of Citrullus colocynthis (L.) Schrad. (Cucurbitaceae) in the United Arab Emirates. J New Biol Rep. 3:145-150.

Rondanini DP, Gomez NV, Agosti MB, Miralles DJ (2012) Global trends of rapeseed grain yield stability and rapeseed-to-wheat yield ratio in the last four decades. Eur J Agron. 37:56-65.

Sanford SD, White JM, Shah PS, Wee C, Valverde MA, Meier GR (2009) Feedstock and biodiesel characteristics report. Report by Renewable Energy Group 416.

Shao JA (2015) New rapid method for the determination of total acid number (tan) of bio-oils. Am J Biomass Bioenerg. 4:1-9.

Sujatha M, Reddy TP, Mahasi MJ (2008) Role of biotechnological interventions in the improvement of castor (Ricinus communis L.) and jatropha curcas 1. Biotechnol Adv. 26(5):424-435.

Tikkoo A, Yadav SS, Kaushik N (2013) Effect of irrigation, nitrogen and potassium on seed yield and oil content of Jatropha curcas in coarse textured soils of northwest india. Soil Till Res. 134:142-146.

Wang YJ (2014) Highly-efficient enzymatic conversion of crude algal oils into biodiesel. Bioresour Technol. 172:143149. 